\title{
定期民間航空による $\mathrm{CO}_{2}$ 排出量の現状と将来予測に関する基礎的研究*
}

\author{
Preliminary Analysis on Current and Future $\mathrm{CO}_{2}$ Emissions from Scheduled Civil Aviation*
}

鈴木崇正**·室町泰徳***

By Takamasa SUZUKI**•Yasunori MUROMACHI***

\section{1. はじめに}

現在、航空機起源の $\mathrm{CO}_{2}$ 排出量は運輸部門におけるそ れの約13\%を占めており、自動車に次いで2番目に大きい。 今後も航空輸送の成長が予想され ${ }^{23)}$ 、輸送量増加に伴う $\mathrm{CO}_{2}$ 排出量増加がさらに進む可能性があることから、航空 機からの $\mathrm{CO}_{2}$ 排出量を予測し、その削減方法を検討寸るこ とは環境負荷低減の観点から有意義である。

これまで、特に米国や欧州では、航空機による然料消費 量・各排出物排出量の算出および予測に関する研究が実 施されてきた。各研究における燃料消費量や排出量の算 出方法に大差はなく、およそ図1に示すスキームの通りであ る。各航空便について、発着地や飛行時間等航空機の運 航データ、航空機種情報を航空時刻表やレーダ一追跡デ 一タ等から取得する。その各機種について、単位時間あた りの燃費・排出データを排出量データベースから取得する ことにより、各フライトの燃料消費量や排出物排出量が算出 される。これを世界の全フライトについて積算することで、 全世界における燃料消費量や排出物排出量が算出される。 米航空宇宙局(NASA) による研究の先駆けの1つである Landau et al. ${ }^{4}{ }^{4}$ は、1990年におけるジェッ小航空機による然料 消費量およびNOx・CO・HCの各排出量の算出に加え、超 音速旅客機の就航を想定した2015年におけるそれらの排 出量予測を実施した。この研究を基礎として、Baughcum et al. ${ }^{5)}$ は1992年の、Sutkus et al. ${ }^{6}$ は1999年の、それぞれ世界 の定期民間航空便を対象とした燃料消費量や各排出物排 出量の算出を行っている。また、過去や将来予測に関する 研究としては、2020年を対象として予測を行ったSutkus et al. ${ }^{7}$ 、過去に遡って1976年と1982年における燃料消費量・排 出物排出量の予測を行ったBaughcum et al. ${ }^{8}$ がある。

NASA以外においても、FAA ${ }^{1)}$ にる2000～2004年を対 象とした分析、欧州民間航空協議会・ANCAT/EC2 ${ }^{9}$ によよる $1991 / 92$ 年と 2015 年を対象とした分析、欧州委員会

*キーワーズ : 交通行動分析、公共交通運用、交通流 **学生員、工修、東京工業大学大学院総合理工学研究科 人間環境システム専攻（神奈川県横浜市緑区長津田町 4259 TEL: 045-924-5606、e-mail:suzuki.t.bb@m.titech.ac.jp) ***正員、工博、東京工業大学大学院総合理工学研究科 人間環境システム専攻
AERO2Kプロジェクト ${ }^{10)}$ による2002年と2025年を対象とした 分析などが行われた。国内では三菱総合研究所11)が空港 における排出物排出量に着目し、成田・羽田・関西 ・伊 丹の国内主要4空港における排出量の実態を示している。

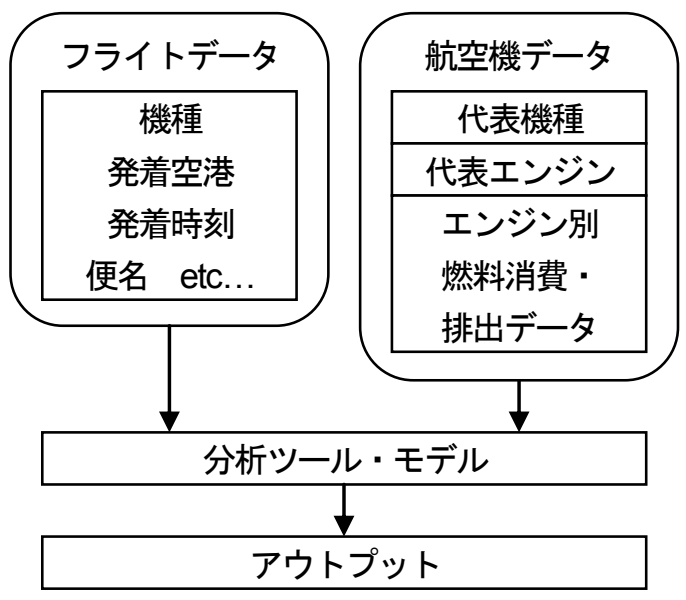

図1. 燃料消費量·排出量算出のスキ一ム

上述の研究の多くはNOxやCOを分析対象とし、 $\mathrm{CO}_{2}$ を直 接分析対象とした研究は少ない。しかし、各研究では然料 消費量が計算されていることから、この值に排出係数 (EI: Emission Index、3.155kg/然料kg) を乗ずることによって $\mathrm{CO}_{2}$ 排出量を求めることが可能である ${ }^{19)}$

より長期的な将来予測として、Olsthoorn ${ }^{12)}$ は2050年を対 象とした $\mathrm{CO}_{2}$ 排出量の変化を、GDPと燃料価格の推移から 予測した。予測に用いたGDPの将来成長シナリオの違いに

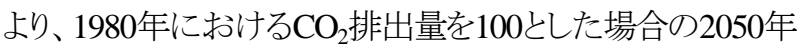
におけるそれの予測值は600から1300まで大きく変化する 可能性が指摘されている。またVedantham et al. ${ }^{13)}$ は、2100 年における航空からの $\mathrm{CO}_{2}$ 排出量は1990年比でおよそ8倍 になると予測した。しかしここでも、分析に用いるシナリオに よって結果が大きく左右されることが述べられている。

本稿ではこれら既往研究に基づき、はじめに全世界に おける定期民間航空機からの2005年の $\mathrm{CO}_{2}$ 排出量の現況 分析を行う。次に2050年までを対象として、全世界の国内 線および国際線の航空需要予測を行うとともに、それに基 づいて予測した将来の $\mathrm{CO}_{2}$ 排出量を示す。既往研究に対し て、個々の国別リンクや航空需要 $\cdot \mathrm{CO}_{2}$ 排出量の地理的分 布を考慮している点が特徴的である。 


\section{2005 年における $\mathrm{CO}_{2}$ 排出量の算出}

2005年の民間定期航空による $\mathrm{CO}_{2}$ 排出量を算出する。全 世界の民間定期航空便を掲載した2005年版OAG 時刻表 ${ }^{14)}$ に含まれる旅客・貨物フライト全便を対象とし、機種、運航 時間、発着地の各フライトデータを抽出した。

図2に示すとおり、各フライトの運航モードを、降下・アイド

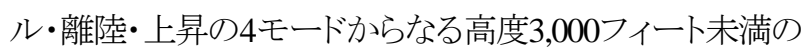
離着陸サイクルと、それ以上の高度における巡航モードに 分割する。離陸滑走以外の地上滞在は全て『アイドル』に含 まれる。各モードの所要時間はICAOが定める值(降下 240 秒、アイドル1560秒、離陸45秒、上昇132秒) とし、時刻表上 の所要時間から離着陸サイクル所要時間を減算したものを 巡航時間しした。フライト時間が離着陸サイクルの総和 32.8 分に満たないものは32.8分に切り上げ、巡航時間は0分とし た。これらの值は元々ジェット機を対象としたものであり、 プロペラ機等においては值が異なる可能性がある。しかし 本稿においては、これらの值を一律にすべての航空便に 適用した。またフライトの遅延は考慮していない。

OAG収録の2005年に運航された210機種の燃料消費量 は、各機種に搭載されているエンジンの単位時間当たり燃 料流量データから算出する。ここで、機種によっては複数 のエンジン種を採用しているものも存在するが、これらにつ いては航空会社に関係なく、各機種において最も採用数の 多いエンジン種をその機種の代表エンジンとした。エンジ ン別・離着陸時の 4 運航モード別の1秒当たり燃料流量が記 載されているデータベース ${ }^{15)-17}$ に基づき、この值に搭載エ ンジン数を乗じたものを各機種の燃料流量とした。また巡航 時の燃料流量はEurocontrol ${ }^{18)}$ を用いたが、このデータベー スに収録されているエンジン種は本分析におけるそれより も少ない。そのため、まずEurocontrolに収録されている各 エンジンについて、巡航時の燃料流量をその他の 3 データ ベースに記載の離陸時の燃料流量と比較したところ、巡航 時の燃料流量は離着陸時のそれの平均約36\%であった。 このことから、巡航時の燃料流量は離陸時のそれの36\%で あると仮定した。また、燃料流量は外気温や気圧、湿度など の影響を受ける可能性があるが、ここでは考慮していない。 以上述べた各フライトの燃料流量に基づく $\mathrm{CO}_{2}$ 排出量の算 出モデルは式(1)の通りである。

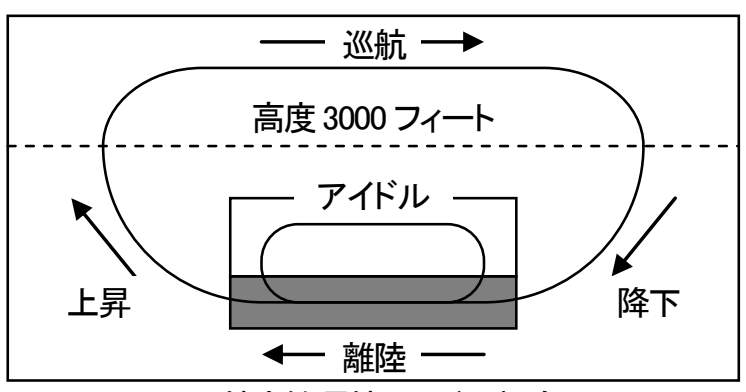

図2. 航空機運航モ一ドの概念図

$$
Q=F \cdot \sum\left(T_{m} \cdot W_{m, p}\right)
$$

$\mathrm{Q}: \mathrm{CO}_{2}$ 排出量 $(\mathrm{g})$

$\mathrm{T}$ : 運航時間 (h)

$\mathrm{W}$ : 燃料流量 (燃料 $\mathrm{g} / \mathrm{h} \cdot$ 機)

$\mathrm{m}:$ 運航モード

p: 航空機種

$\mathrm{F}: \mathrm{CO}_{2}$ 排出係数 $\left(3.155\left(\mathrm{CO}_{2} \mathrm{~g}\right.\right.$ 燃料 $\left.\left.\mathrm{g}\right)\right)$

以上より、2005年における全世界の民間定期航空 $\mathrm{CO}_{2}$ 排 出量は630.3Tgと算出された。この值を既往研究における算 出値と比較すると、ほぼ同等な結果が得られている。

\section{2050 年までを対象とした将来 $\mathrm{CO}_{2}$ 排出量予測}

次いで、 $\mathrm{CO}_{2}$ 排出量の将来予測のために、始めに全世界 の国内線および国際線における旅客・貨物需要予測を 別々に行い、続いてその結果に基づき $\mathrm{CO}_{2}$ 排出量予測を 行う。基本的な $\mathrm{CO}_{2}$ 排出量算出手法は2005年現況算出に用 いたものと同一であるが、次の点が異なる。第一に需要予 測では国内線と国際線を別々に扱っている点、第二に需要 予測は国単位で実施している点である。

OAG時刻表に収録の、2005年の民間定期便就航国・地 域数は223であるが、後に述べる人口・GDPデータベース にデータがなかったことから、クリスマス島・ココス諸島・ノー フォーク島はオーストラリアに、マヨットはコモロに統合した。 このため予測に用いられたのは合計219个国・地域である。 旅客便は全219 个国に、貨物搭載可能な旅客便と貨物専用 便は214ケ国に就航している。これ以降、貨物を対象とした 将来予測においては旅客機による貨物輸送を含むものと する。民間定期便が就航していない国の大半は、空港設置 に十分な国土を有していないか政治的情勢から定期便が 就航できていない国であり、将来の定期便就航の可能性も 低いか不確実であると考えられることから、将来においても 定期便就航国は不変とした。

将来需要予測には各国の人口、GDPの予測データ、各 国間の大圈距離を説明変数とする重力モデルを用いた。 2050 年までの人口予測データは $\mathrm{UNPD}^{19)}($ 台湾のみ $\left.\mathrm{USCB}^{20)}\right) 、 2005$ 年のGDPデータはUNSD ${ }^{21)}$ 用いた。また 2050年までのGDPは、各国の1990-2005年のGDP成長率が 将来も持続すると仮定して算出した。各国間の大圈距離の 算出には各国の位置座標が必要であるが、ここでは各国に おける国際線旅客数が最多の空港の位置座標をその座標 とした。多くの国では首都が該当するが、米国はニューヨー ク、カナダはトロント、ドイツはフランクフルトなど、首都と一 致しない場合も存在する。各航空機種の定員および最大貨 物積載量はOAG時刻表に記載のとおりとした上で、旅客搭 乗率と貨物積載率の双方とも70\%と仮定した。 
以下の需要予測は、2010年から2050年まで5年間隔、計9 ケースについて行った。需要予測結果は2050年について のみ示し、 $\mathrm{CO}_{2}$ 排出量推定結果は全9ケースについて示す。

\section{(1) 国内線需要予測}

分析に用いる219ケ国中、国内線が就航しているのは旅 客便が150ケ国、貨物便が110ケ国である。本稿では、国内 線就航国は将来に渡って不変であるとする。

国内線需要予測は、式(2)に示すモデルに基づいて行う。 まず2005年における人口・GDP・距離データを用いてパラ メータ推定を行い、次いでそのパラメータを用いて将来需 要予測を行う。ここで平均フライト距離とは、各国国内線に おける総旅客キロ・総貨物卜ンキロを総旅客数・総貨物卜ン 数で除したものである。また、米国のみ国内線需要が突出 しており他国とは異なる需要傾向を示すため、定数項につ いては米国以外と米国の2つの場合を分けるダミーとした上 で、米国と他国で同一のモデルが使用できるよう配慮した。

2005年におけるデータをこの式に適用して推定されたパ ラメータと、算出された2050年国内線輸送量は表1および表 2の通りである。人口、GDP、距離の各パラメータはいずれ も有意水準 $5 \%$ で有意であった。旅客と貨物の双方におい て、このモデルは90\%以上の説明力を有している。2050年 における国内線需要予測においては、2005年からの45年 間で約1.6〜2.7倍の伸びが示された。

$$
Q_{y}=\exp \left[\alpha_{1} \ln \left(P_{y}\right)+\alpha_{2} \ln \left(G_{y}\right)+\alpha_{3} D+\alpha_{4}\right](2)
$$

$\mathrm{Q}_{\mathrm{y}}$ ：対象年 $\mathrm{y}$ の旅客数 $($ 人) ・貨物輸送量 $(\mathrm{t})$

$\mathrm{P}_{\mathrm{y}}$ : 各国の対象年 $\mathrm{y}$ の総人口 (人)

$\mathrm{G}_{\mathrm{y}}$ : 各国の対象年 $\mathrm{y} の \mathrm{GDP}(\mathrm{USD} /$ 人)

$\mathrm{D}$ : 平均フライト距離 $(\mathrm{km})$

$\mathrm{y}$ : 対象年

$\alpha_{1} \sim \alpha_{4}:$ パラメータ

\section{表1. 国内線需要予測におけるパラメータ推定結果}

\begin{tabular}{l|rrrr}
\hline パラメータ & 旅客 & $(\mathrm{t}$ 值) & 貨物 & $(\mathrm{t}$ 值) \\
\hline 人口 & $.636^{*}$ & 9.187 & $.624^{*}$ & 5.460 \\
$\mathrm{GDP}$ & $.691^{*}$ & 8.219 & $.497^{*}$ & 4.032 \\
距離 & $.002^{*}$ & 3.928 & $.002^{*}$ & 3.434 \\
定数(米国以外) & $-3.376^{*}$ & -2.520 & $-5.725^{*}$ & -2.586 \\
定数(米国) & -2.254 & -1.016 & -4.668 & -1.447 \\
\hline $\mathrm{R}^{2}$ & .987 & - & .962 & - \\
観測数 & 150 & & 110 & \\
\hline
\end{tabular}

*: 有意水準 $5 \%$ で有意

表2. 2050年国内線需要予測結果

\begin{tabular}{l|rrr}
\hline 予測対象 & 2005年 & 2050年 & 率 \\
\hline 旅客 (10億人) & 1.4 & 3.5 & $247.5 \%$ \\
旅客 (1兆人 $\mathrm{km})$ & 1.4 & 3.8 & $270.3 \%$ \\
貨物 $(100$ 万t) & 37.3 & 61.5 & $165.0 \%$ \\
貨物 $(10$ 億t-km) & 50.0 & 96.9 & $193.7 \%$ \\
\hline
\end{tabular}

\section{(2) 国際線需要予測}

国際線需要予測の手順を図3に示す。先に述べたとおり、 国際線の分析は各航空路線を国対国のリンクに置換して実 施する。2005年においては、組み合わせ可能な 219x218=47,742通りの国際線リンク(往復を別リンクとして扱 う)のうち、旅客ネットワークとして4,684リンク、貨物ネットワ 一クとして4,070リンクが存在している。ここで、OAG時刻表 から直接求められる旅客・貨物輸送量は全て各国間の断面 輸送量であり、正確な各国間OD交通量を示すものではな いことに注意しなければならない。図4に示すとおり、国XY 間の断面交通量には国XY間のOD交通量の他に、第3国 から、あるいは第3国へのOD交通量も含まれている可能性 がある。さらに図中の破線で示すように、それら第3国を発 着するODが国XY間リンクを経由しなくても成立する場合、 これら第3国を発着し国XY間リンクを経由するODはその全 てではなく一部である可能性もある。以上から、国際線の将 来需要予測にあたっては各国の社会経済属性や距離デー 劢ら各国間のOD交通量を求め、さらにそれを踏まえて各 国間断面交通量を推定することが必要である。本稿では国 際線将来需要予測にあたり、まず任意の2国間に国際線リ ンクが張られる可能性を推定して、予測対象年における旅 客と貨物の国際線ネットワークを構築する。次に各国間の OD交通量を予測し、ダイヤル法 ${ }^{2223)}$ を用いて各リンクに配 分する。ダイヤル法はある2点間の交通があるネットワーク 内の任意のリンクを経由する確率を計算するものである。こ うて求められた各少ンク断面交通量を全ての各国間ODぺ アについて積算し、各国間断面交通量を算出する。なお、 2005年時点で存在するリンクは将来にわたって存在するも のとする。

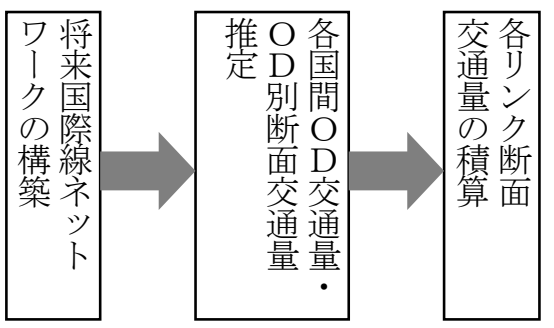

図3. 国際線需要予測の手順

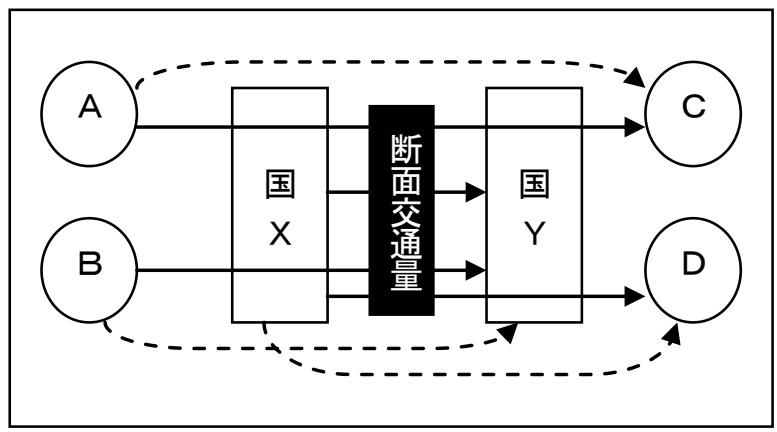

図4. 国XY間断面交通量の概念 
任意の2国間にリンクが張られる可能性は式(3)に示す口 ジットモデルによって算出する。そしてモデルにより判定さ れた2005年におけるリンクの有無と同年の実際のリンクの 有無が一致しているリンク数を全少クク数で除した值を少ンク の再現率しし、その再現率の最も高い $\mathrm{L}_{\mathrm{ij}}$ の值を、将来予測 においてリンクの張られる確率の閾值と寸る。説明変数に は各国の人口とGDPの予測值、および各国間の距離を用 いた。ここで定数項は、総人口が突出して多い中国とインド の影響を明示的に考慮するため、2国の人口合計が10億人 未満およびそれ以上を分けるダミーとした。なお、2005年に はリンクが存在しない2国間における将来のリンク出現を考 慮していることから、2国間距離はOAGに記載された運航 距離ではなく各国の位置座標から球面三角法を使用して算 出した。

パラメータ推定結果を表3に示す。このパラメータを用い て2005年航空ネットワークを再現した結果、旅客・貨物とも に $\mathrm{L}_{\mathrm{ij}}=0.50$ の場合に再現率が最高であり、その值は旅客で 90.2\%、貨物で92.8\%であった。よって将来の各国の社会経 済属性予測データを用いて $\mathrm{L}_{\mathrm{ij}}$ が0.50以上となるリンク、およ び2005年時点で存在するリンクにより予測対象年における 国際線旅客・貨物ネットワークを構築した。2050年における リンク数は旅客8,356、貨物7,754である。

$$
L_{i j}=\frac{\exp (V)}{\exp (V)+1}
$$

$$
\begin{aligned}
& V=\beta_{1} \ln \left(P_{i} P_{j}\right)+\beta_{2} \ln \left(G_{i} G_{j}\right)+\beta_{3} D_{i j}+\beta_{4} \\
& \mathrm{~L}_{\mathrm{ij}}: \text { 国 } \mathrm{ij} \text { 間にリンクが張られる確率 } \\
& \mathrm{P}_{\mathrm{i}}: \text { 国 } \mathrm{i} \text { の人口 }(\text { 人) } \\
& \mathrm{G}_{\mathrm{i}}: \text { 国 } \mathrm{i} \text { のDP }(\mathrm{USD} / \text { 人) } \\
& \mathrm{D}_{\mathrm{ij}}: 2 \text { 国 } \mathrm{ij} \text { 間距離 }(\mathrm{km}) \\
& \beta_{1} \sim \beta_{4}: \text { パラメータ }
\end{aligned}
$$

\begin{tabular}{l|rrrr}
\multicolumn{5}{c}{ 表3. 国際線リンク予測におけるパラメ一タ推定結果 } \\
\hline パラメータ & 旅客 & $(\mathrm{t}$ 值) & 貨物 & $(\mathrm{t}$ 值 $)$ \\
\hline 人口 & $.734^{*}$ & 37.582 & $.797^{*}$ & 44.241 \\
GDP & $.608^{*}$ & 38.120 & $.680^{*}$ & 38.979 \\
距離 & $-.590 \mathrm{e}-03^{*}$ & -60.682 & $-.509 \mathrm{e}-03^{*}$ & -61.401 \\
定数(10億人以下) & $-17.367^{*}$ & -42.728 & $-19.709^{*}$ & -52.262 \\
定数(10億人超) & $-17.883^{*}$ & -37.530 & $-20.313^{*}$ & -46.703 \\
\hline 初期尤度 & $33,092.233$ & & $31,595.035$ & \\
最終尤度 & $8,890.972$ & & $8,353.029$ & \\
観測数 & 4,684 & & 4,070 & \\
\hline
\end{tabular}

*: 有意水準 $5 \%$ で有意

続いて断面交通量予測を行う。国XY間の断面交通量は、 任意の2国間のOD交通量にそのOD交通量が国XY間リン クを通過する確率を掛けたものを、全ての2国間ODについ て積算したものである。この確率はダイヤル法を用いて算
出した。その際、シータの值は100とした。また各フライトの 所要時間(h)は、2005年実績に基づきフライト距離から算出 し、さらに搭乗手続き・乗換抵抗として各フライトの所要時間 に2時間を加算した。ダイヤル法を用いた各林断面交通 量算出モデルは式(4)の通りである。このモデルでは2国の 人口、GDP、距離力ら2国間OD交通量とOD別少ンク交通量 を算出し、それを全2国間ODについて行うことによって各リ ンクの合計交通量が算出される形式となっている。このモ デルおよび2005年実績断面交通量を用いて推定されたパ ラメータと、推定されたパラメータを使用して算出された 2050年国際線旅客・貨物輸送量を表4および表5に示す。 2050年における国際線輸送量は、旅客数および貨物トン数 ベースで2005年と比べて約11倍、人キロ・トンキロベースで 2005年と比べて約16-17倍であった。旅客におけるモデル の説明力が60\%を超えた一方、貨物におけるそれは39\%と 低いものであった。旅客機には貨物搭載スペースも存在し、 旅客之同時に貨物の輸送も担っているが、Oster et al. ${ }^{24)}$ は、 旅客機の運航は旅客流動に最適化されていて、貨物流動 を十分に反映していないことを述べている。このことから、 旅客と貨物の双方に対して同一のモデルを適用することは、 貨物輸送の予測に対して説明力低下の一つの要因になつ ているものと考えられる。また説明力が比較的低かった別 の要因として、空港の厳密な位置を考慮せず1国1ノードと して計算を行ったことが考えられる。この結果、例えば欧米 路線では過少に、日米路線では過大に予測がなされてい る可能性がある。

$$
\begin{aligned}
Q_{i j}=\sum_{A, B} C_{A B i j} \cdot\left(P_{A} P_{B}\right)^{\gamma_{1}} & \cdot\left(G_{A} G_{B}\right)^{\gamma_{2}} \\
\cdot & \exp \left(\gamma_{3} D_{A B}\right) \cdot \gamma_{4}
\end{aligned}
$$

$$
\begin{aligned}
& \mathrm{Q}_{\mathrm{ij}} \text { : 国ij間リンクの断面交通量 } \\
& \mathrm{C}_{\mathrm{ABj}} \text { : 国 } \mathrm{AB} \text { 間の交通が国ij間リンクを通る確率 } \\
& \mathrm{P}_{\mathrm{A}}, \mathrm{P}_{\mathrm{B}} \text { : 国A,Bの人口(人) } \\
& \mathrm{G}_{\mathrm{A}}, \mathrm{G}_{\mathrm{B}} \text { : 国A,BのGDP(USD/人) } \\
& \mathrm{D}_{\mathrm{AB}} \text { : 国 } \mathrm{A}, \mathrm{B} \text { 間の航空路距離 }(\mathrm{km}) \\
& \gamma_{1} \sim \gamma_{4}: \text { パラメータ }
\end{aligned}
$$

表4. 国際線需要予測におけるパラメ一タ推定結果

\begin{tabular}{l|rrrr}
\hline パラメータ & 旅客 & $(\mathrm{t}$ 值) & 貨物 & $(\mathrm{t}$ 值) \\
\hline 人口 & $.793^{*}$ & 76.318 & $.816^{*}$ & 22.933 \\
$\mathrm{GDP}$ & $.760^{*}$ & 49.180 & $.841^{*}$ & 17.067 \\
距離 & $-.294 \mathrm{e}-03^{*}$ & -57.469 & $-.773 \mathrm{e}-04^{*}$ & -6.447 \\
定数(10億人以下) & $.323 \mathrm{e}-12^{*}$ & 2.295 & $.234 \mathrm{e}-15$ & 0.713 \\
定数(10億人超) & $.208 \mathrm{e}-12^{*}$ & 2.286 & $.249 \mathrm{e}-15$ & 0.709 \\
\hline $\mathrm{R}^{2}$ & .613 & - & .390 & - \\
観測数 & 4,684 & & 4,070 & \\
\hline
\end{tabular}

*: 有意水淮5\%で有意 
表5. 2050年国際線需要予測結果

\begin{tabular}{l|rrr}
\hline 予測対象 & 2005 年 & 2050 年 & 率 \\
\hline 旅客 $(100$ 万人) & 803.5 & 8942.5 & $1112.9 \%$ \\
旅客 $(1$ 兆人 $\mathrm{km})$ & 2.2 & 36.1 & $1608.6 \%$ \\
貨物 $(100$ 万 $\mathrm{t})$ & 42.5 & 466.0 & $1095.9 \%$ \\
貨物 $(10$ 億t-km) & 175.0 & 3048.3 & $1741.7 \%$ \\
\hline
\end{tabular}

(3) $\mathrm{CO}_{2}$ 排出量予測

将来の $\mathrm{CO}_{2}$ 排出量予測には、以下の 4 ステップを用いる。 まず各国の国内線および各国際線リンクに対し代表機種を 割り当てる。次に、先に算出した需要予測值およびその代 表機種の旅客定員に基づき、各国内線および国際線リンク における航空便数を算出する。さらに、旅客便で運送でき る貨物容量より予測された貨物輸送量が大きかった場合、 そのリンクに対し貨物専用便を補完的に設定寸る。以上の プロセスにより、各リンクに割り当てられた機種および便数 に基づき、 $\mathrm{CO}_{2}$ 排出量を算出する。

はじめに各リンクにおける代表機種を選択する。通常、 各航空路における航空便は複数の機種で運航されており、 その機種選択は航続距離や輸送量などに依存寸る。しかし ここでは計算の簡略化のため、将来にわたって使用される 航空機種を7機種選出し、そのうちのいずれかの機種が各 リンクにおいて代表機種として使用されると仮定した。選出 された7機種はA380-800、B777-300ER、A340-300、A321100、B737-700、ERJ-170およびB747-400Fである25-27)。これ らのうち貨物専用機であるB747-400F以外は旅客および貨 物の双方を輸送することが可能である。これらの機種の選 出基準はキャパシテイおよび航続距離が互いに異なってい ること、一般的に使用されている機種であること、比較的新 しい機種であり現在も生産が続いていることである。各リン クにおける代表機種の選択にあたっては、各少クの平均 フライト距離から機種を推定し、そのリンクにおける代表機 種とした。

次に、選出された各リンクの代表機種の定員に旅客平均 搭乗率の0.7を乗じ、 1 便あたり輸送力を算出寸る。この值で 各リンクの予測旅客輸送量を除寸ることにより、各リンクに おける予測便数が計算される。生じた端数は切り上げる。

これまでは旅客について注目したが、各リンクには貨物 輸送も存在する。まず先に指定した各代表機種の最大貨物 積載量に積載率 0.7 を乗じ、 1 便あたりの貨物輸送力を求め る。この量に先ほどの予測便数を乗じたものが各少ンクお ける予測貨物輸送力であり、この值が各リンクの予測貨物 需要を上回っていれば、貨物は全て旅客とともに輸送でき るものとみなす。一方輸送力が輸送量を下回っている場合 には、上記予測便数のみでは輸送できない貨物が発生す ることになる。この場合、輸送力を超過した貨物を輸送でき る分だけ貨物専用便を設定する。貨物専用便は全てB747400Fが用いられるものとし、その貨物積載率は最大積載量
の0.7倍であるとして貨物専用便の便数予測を行った。

最後のステップとして、これまでに予測してきた各リンク における機種および便数から、式(1)(4)を用いて将来の $\mathrm{CO}_{2}$ 排出量を算出する。ここで、将来の燃費改善を考慮し なければならない。Balashov et al. ${ }^{28}$ は、2010年までの航空 燃費の改善率は年間 $2.5 \%$ あるると予測し、Greene ${ }^{29)}$ も、同心゙ 期間における改善率は年間1.3\%であると述べている。本稿 では、2050年までの全ての年にわたってGreeneによる燃費 改善率を適用した。最終的に求められた2050年までの $\mathrm{CO}_{2}$ 排出量予測值を、既往研究による值とともに図5に示す。 2050年における全世界の航空からの $\mathrm{CO}_{2}$ 排出総量予測值 は3944.2Tgであった。この值は2005年からの 45 年間で6.3 倍の伸びに相当する。特に国内線が1.5倍であったのに対 し国際線は8.9倍であり、全体に占める国際線の割合も2005 年における65\%から2050年の92\%に増加している。2025年 までの予測值については、本稿における算出結果は既往 研究におけるそれより若干低く、2015年においてANCAT ${ }^{9}$

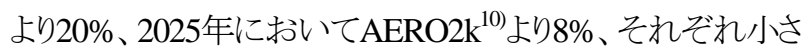
い值となった。この理由として、将来の使用機種を新鋭の7 機種に限定したことや、2国間の最短の大圈距離をフライト 距離として用いたことなどが考えられる。また、先述のとおり 実際には旅客便の運航は貨物輸送には必ずしも最適化さ れていない一方で、本分析では旅客機で最大限貨物輸送 が行われていると仮定しており、実際より輸送効率を過大評 価ててる可能性があることもその理由であると考えられる。

以上の予測は45年もの長期を対象にしたものであり、か つ将来の人口とGDPが別々に予測されていることから、こ の予測における不確実性は比較的大きいものと考えられる。 そこで将来の人口とGDPの予測值の変化による $\mathrm{CO}_{2}$ 排出量 予測值の変化を確認するため、感度分析を行った。将来の 人口予測值を $10 \%$ 増減させた結果、 $\mathrm{CO}_{2}$ 排出量の予測値は 2030年において約14\%、2050年において約16\%、それぞ れ増減した。また、GDPを $10 \%$ 増減させた場合の $\mathrm{CO}_{2}$ 排出 量予測值の増減幅は、人口におけるそれとほぼ同等であ った。このことから、将来予測に用いる人口やGDPのシナリ オの違いにより、 $\mathrm{CO}_{2}$ 排出量の将来予測值に大きな差が生 じる可能性が示されたと言える。

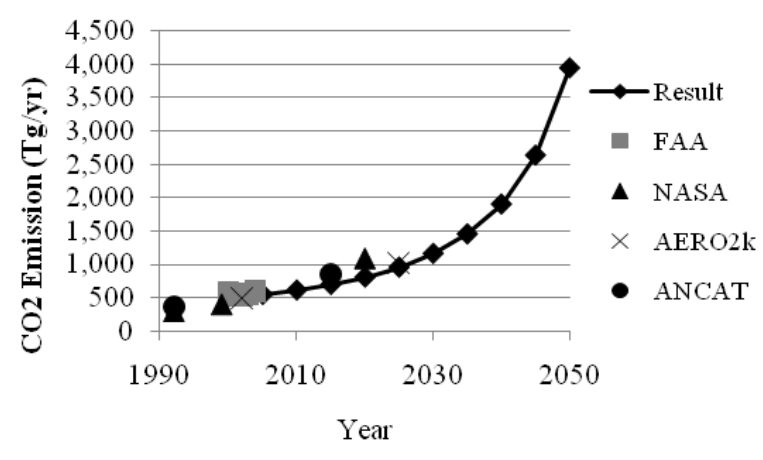

図5. $\mathrm{CO}_{2}$ 排出量の将来予測値 


\section{4. $\mathrm{CO}_{2}$ 排出量の地理的考察}

2005年における $\mathrm{CO}_{2}$ 排出量の現状と2050年における排 出量予測值の地理的分布をそれぞれ図6、図7に示寸。こ れらの図は、算出された $\mathrm{CO}_{2}$ 排出量を緯度 1 度・経度1度の グリッドごとに配分したものである。2005年では、航空から の $\mathrm{CO}_{2}$ 排出量は北米、ヨーロッパ、東および東南アジアに 集中している。また大西洋横断航空路およびユーラシア大 陸横断航空路における排出量も多い。その一方で中南米 やアフリカ、オセアニアなどでは $\mathrm{CO}_{2}$ 排出量は比較的少な い。これらの地域では航空による旅客・貨物輸送量が少な いことから、航空機の使用も希薄であることが推察される。

2050 年における $\mathrm{CO}_{2}$ 排出量分布は、2005年におけるそ れとは大きく異なる。まず、図7で示したように2050年におけ るCO 排出量は2005年と比較して大幅に伸びている。全体 として $\mathrm{CO}_{2}$ 排出量が多い地域が著しく増加し、排出量が

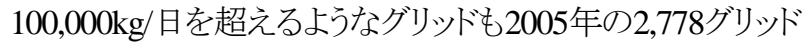
から12,446グリッドへと約4.5倍となった。これら排出量が特 に多い地域はこれまでの北米やヨーロッパ等にとどまらず、 アジアやアフリカにも集中している。将来における航空需 要の伸びやそれに伴う $\mathrm{CO}_{2}$ 排出量の増加が、特定の地域 に限られたものではなく全世界的な傾向として広まる可能 性があることが示唆される。

図8には、2005年から2050年までのグリッドごとの $\mathrm{CO}_{2}$ 排 出量の変化を示す。欧米のみならずアジアやアフリカなど における排出量の増加が顕著であり、2005年から2050年ま での間に中国で28倍、インドで14倍、ナイジェリアで11倍の 伸びであった。一方日本と米国は2.7倍であった。特にアフ リカでは、急激な人口の増加と途上国における経済水準の 向上により、将来大幅に航空需要が増加すると予測されて いる。また、これまでは距離が長く国際便が就航していなか った2国間においても、人口増加やGDP上昇とともに航空 路で結ばれると予測されるケースがみられる。例えばアジ アと南米とを結ぶ航空路がそれに該当する。これらの路線 では、技術向上とともに航続距離のより長い航空機が生産 されることにより、2国間を直接飛行する航空便が実現する ものと考えられる。

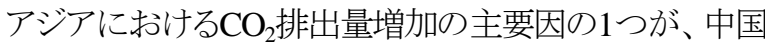
とインドにおける急速な経済成長である。この2国では将来 にわたって大幅な経済成長が見込まれているほか、人口に ついても中国で1億人が、インドでは5億人が今後45年間で 増加するものと予測されている。この2国を含め、人口の多 いアジア国家における経済成長がさらなる旅客・貨物需要 をもたらし、結果として $\mathrm{CO}_{2}$ 排出量を増加させる大きな要因 になるものと考えられる。

以上の点から、次のことが指摘できる。第一に、年間 $1.3 \%$ の燃費向上を考慮しても、2050年までに6倍もの $\mathrm{CO}_{2}$ 排出量増加が予測される。人口増加も今後数十年にわたつ

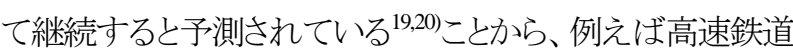
など航空機に対抗しうる交通機関の導入など、 $\mathrm{CO}_{2}$ 排出量 を抑制する強い方策が不可欠である。第二に、特に途上国 において将来の $\mathrm{CO}_{2}$ 排出量増加が顕著である。これらの 国々では燃費効率の悪い古い機材を現在でも使用してい るケースが多いと考えられることから、より効率的な新しい 機材一の更新が排出量抑制に効果的であると考えられる。 また、将来の輸送量増加に対応し、平均搭乗率や貨物積載 率を向上させ輸送効率を改善することも必要である。

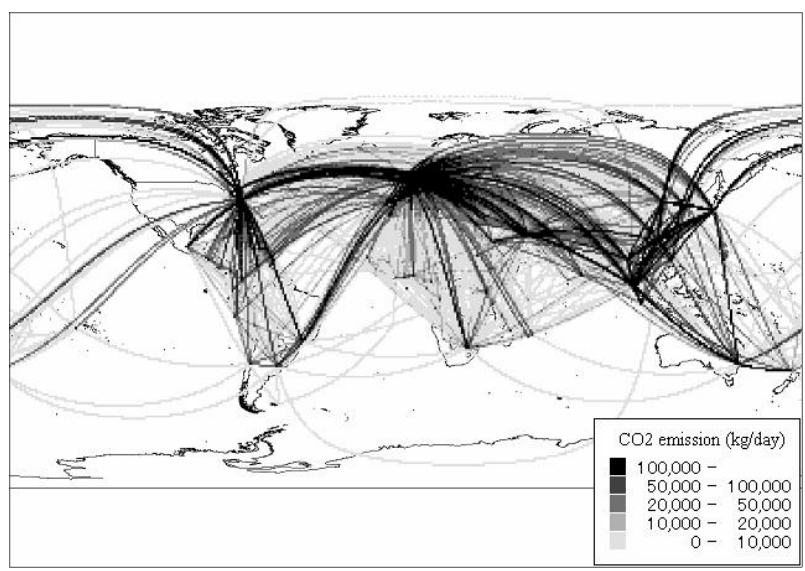

図 6. 2005 年における $\mathrm{CO}_{2}$ 排出量分布

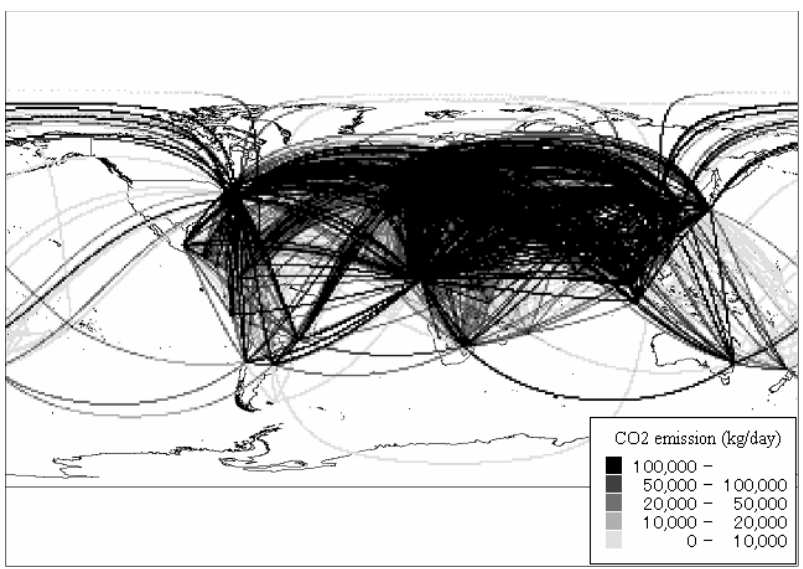

図 7. 2050 年における $\mathrm{CO}_{2}$ 排出量分布

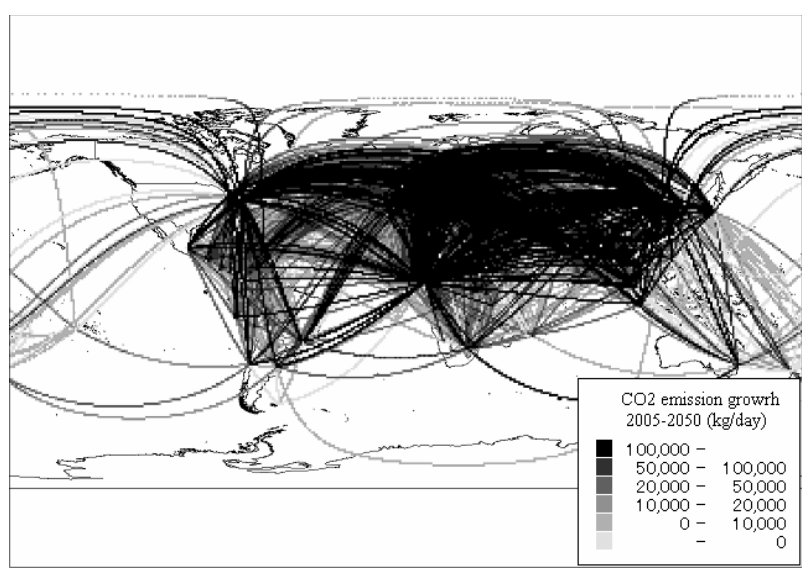

図 8. 2005 年から 2050 年までの $\mathrm{CO}_{2}$ 排出量変化 


\section{5. おわりに}

本稿では、2005年における航空によるCO 2 排出量を算出 するとともに、2050年までの将来における航空需要予測、 およびその結果に基づく $\mathrm{CO}_{2}$ 排出量の予測を行った。その 結果、航空からの $\mathrm{CO}_{2}$ 排出量は2005年で630.3Tg、2050年 で3944.2Tgであると予測された。地理的分析においては、 特にアジアやアフリカにおける将来の $\mathrm{CO}_{2}$ 排出量の著しい 伸びが示唆された。

今回の分析では、旅客と貨物に同一のモデルを適用し ているが、貨物におけるパラメータの妥当性が旅客におけ るとれと比して小さものであった。前述のとおり、航空機 の運用は旅客流動に最適化されていることが多く、貨物流 動を十分に反映していない可能性が考えられることから、 特に貨物輸送についてより妥当性の高いモデルの導入の 検討が必要である。また、将来の人口やGDPの異なる予測 シナリオを排出量予測に用いることによって、異なる排出量 予測結果が示される可能性がある。特に、GDP成長率に関 して今後45年間にわたって過去の伸び率と同一であるとい う仮定は、将来の経済構造・成長の変化等を考慮に入れて 見直さなければならない。さらに、今後は新技術の導入等 によって航空機の経済性は向上し、 $\mathrm{CO}_{2}$ 排出量原単位は削 減されることが期待されている。技術向上に伴う燃費改善等 についても予測に含めることが、より正確な $\mathrm{CO}_{2}$ 排出量の将 来予測には不可欠である。また、本研究で示したモデルの 妥当性検証のために、過去の航空時刻表等に示された需 要と本モデルによる予測需要との照合が有効であると考え られる。

\section{参考文献}

1) Kim, B. et al.: System for Assessing Aviation's Global Emissions (SAGE) Version 1.5: Global Aviation Emissions Inventories for 2000 through 2004. FAA-EE2005-02. FAA Office of Environment and Energy, Washington, DC, USA, 2005.

2) Airbus Industrie: Global Market Forecast: The Future of Flying 2006-2025. Airbus S.A.S., Blagnac Cedex, France, 2006.

3) Boeing: Current Market Outlook 2006. Boeing Commercial Airplanes, Seattle, WA, USA, 2006.

4) Landau, Z.H. et al.: Jet Aircraft Engine Exhaust Emissions Database Development - Year 1990 and 2015 Scenarios. NASA/CR-4613. NASA Langley Research Center, Hampton, VA, USA, 1994.

5) Baughcum, S.L. et al.: Scheduled Civil Aircraft Emission Inventories for 1992: Database Development and Analysis. NASA/CR-4700. NASA Langley Research Center, Hampton, VA, USA, 1996a.
6) Sutkus, D.J. et al.: Scheduled Civil Aircraft Emission Inventories for 1999: Database Development and Analysis. NASA/CR-2001-211216. NASA Langley Research Center, Hampton, VA, USA, 2001.

7) Sutkus, D.J. et al.: Commercial Aircraft Emission Scenario for 2020: Database Development and Analysis. NASA/CR-2003-212331. NASA Langley Research Center, Hampton, VA, USA, 2003.

8) Baughcum, S.L. et al.: Scheduled Civil Aircraft Emissions Inventories for 1976 and 1984: Database Development and Analysis. NASA/CR-4722. NASA Langley Research Center, Hampton, VA, USA, 1996b.

9) Gardner, R.M. (Ed.): ANCAT/EC2 Global Aircraft Emissions Inventories for 1991/92 and 2015. Report by the ECAC/ANCAT and EC Working Group, 1998.

10) Eyers, C.J. et al.: AERO2k Global Aviation Emissions Inventories for 2002 and 2025. Report to European Commission, QINETIQ, Farnborough, Hampshire, United Kingdom, 2004.

11）三菱総合研究所 : 平成11年度空港環境保全対策検討調査 報告書, 2000 .

12) Olsthoorn, X.: Carbon dioxide emissions from international aviation: 1950-2050, Journal of Air Transport Management, Vol. 7, pp. 87-93, 2001.

13) Vedantham, A. and Oppenheimer, M.: Long-term scenarios for aviation: Demand and Emissions of $\mathrm{CO}_{2}$ and NOx, Energy Policy, Vol 26, No. 8, pp. 625-641, 1998.

14) Official Airline Guide: OAG Worldwide Timetable, 2005.

15) ICAO: ICAO Engine Exhaust Emission Databank, 1995.

16) Swedish Defense Research Agency (FOI): Confidential Database for Turboprop Engine Emissions, 2007.

17) Swiss Federal Office of Civil Aviation (FOCA): Aircraft Piston Engine Emissions Data, 2007.

18) Eurocontrol Experimental Centre: Aircraft Performance Summary Tables for the Base of Aircraft Data, 2004.

19) UN Population Division: Annual Estimates and Projections, 2007.

20) US Census Bureau: International Data Base, 2006.

21) UN Statistics Division: National Accounts Main Aggregates, 2007.

22) Dial, R.B.: A probabilistic multipath traffic assignment model which obviates path enumeration, Transportation Research, Vol. 5, No. 2, pp. 83-113, 1971.

23) Sheffi, Y.: Transportation Networks. Prentice-Hall Inc., Englewood Cliffs, New Jersey, 1985.

24) Oster, Jr., C.V. and Miles-Mclean, R.: Air cargo: Impacts of adapting to deregulation, Transportation Research Record: Journal of the Transportation Research Board, No. 
1147, pp. 25-33, Transportation Research Board of the National Academies, Washington, DC, USA, 1987.

25) Airbus S.A.S.: Aircraft Families. www.airbus.com/en/aircraftfamilies/. Accessed Jul. 31, 2008.

26) Boeing: Commercial Airplane Products. www.boeing.com/commercial/prodicts.html. Accessed Jul.31, 2008.

27) Embraer: Embraer Commercial Jets. www.embraercommercialjets.com/english/content /hme_ejets/. Accessed Jul. 31, 2008.

28) Balashov, B. and Smith, A.: ICAO analyses trends in fuel consumption by world's airlines, ICAO Journal, Vol. 47, No.8, pp. 18-21, 1992.

29) Greene, D.I.: Energy-efficiency improvement potential of commercial aircraft, Annual Review of Energy and the Environment, Vol. 17, pp. 537$574,1992$.

\section{定期民間航空による $\mathrm{CO}_{2}$ 排出の現状と将来予測に関する基礎的研究*}

鈴木崇正**・室町泰徳*** 本研究では、航空機力ららのCO2排出量削減研究に資する基礎的分析として、2005年における定期民間航空機力らの CO2排出量の算出を行うとともに、2050年までを対象とした将来のCO2排出量の予測を行った。分析の結果、2050年ま での45年間でCO2排出量がおよそ6.3倍になることが示された。CO2排出量の地理的分布の考察では、現在ではヨーロ ツパや北米における排出の集中が確認されたが、将来にわたっては特にアジアやアフリカなどにおける急速な航空需 要の高まりに伴うCO2排出量の著しい増加が示唆された。

\section{Preliminary Analysis on Current and Future $\mathrm{CO}_{2}$ Emissions from Scheduled Civil Aviation*}

By Takamasa SUZUKI**•Yasunori MUROMACHI***

We first calculate the total $\mathrm{CO}_{2}$ emission from scheduled civil aviation in 2005 and then the future forecast of $\mathrm{CO}_{2}$ emission for every five years towards 2050 is conducted. The estimation of future traffic is followed by the calculation of the future $\mathrm{CO}_{2}$ emission. The estimated total $\mathrm{CO}_{2}$ emission in 2005 and 2050 is $630.3 \mathrm{Tg}$ and $3944.2 \mathrm{Tg}$ respectively. The distribution of $\mathrm{CO}_{2}$ emission is discussed from the geographical perspective. The current $\mathrm{CO}_{2}$ emission is concentrated in North America, Europe, and Asia; however, a significant increase in $\mathrm{CO}_{2}$ emission is expected in Asia and Africa. 